\title{
La eficacia y la ejecución de las sanciones de tráfico*
}

\author{
Lucía Alarcón Sotomayor \\ Profesora Colaboradora Doctora de Derecho Administrativo \\ Facultad de Derecho. Universidad de Córdoba
}

\begin{abstract}
Resumen
La regla general que rige en nuestro Derecho es que los actos administrativos obligan directamente y producen efecto desde que se dictan y notifican y que, en caso de incumplimiento voluntario por el interesado, cuando el acto le imponga un comportamiento, la Administración puede proceder a su inmediata ejecución sin necesidad de acudir a un juez. Frente a esa regla general, el legislador ha retrasado la eficacia de las sanciones administrativas a un momento posterior en el art. 138.3 Ley 30/1992 y otros preceptos similares de leyes sectoriales. No obstante, uno de los objetivos de la Ley de reforma 18/2009, de 23 de noviembre, ha sido que las multas de tráfico produzcan efectos y puedan ejecutarse cuanto antes y ello no encuentra inconvenientes ni en la presunción de inocencia ni en la tutela judicial efectiva, pero dicha ley lo ha hecho de una forma tal que parece haber incurrido en una flagrante contradicción que, pese a todo, puede ser superada mediante una interpretación integradora y armoniosa de la ley.
\end{abstract} España.

\section{The efficiency and the execution of the sanctions of traffic}

\begin{abstract}
The general rule that applies in our Law is that the administrative acts force directly and produce effect since they are dictated and notify and that, in case of voluntary breach for the interested party, when the act imposes a behavior on him, the Administration can proceed to his immediate execution without need to come to a judge. Opposite to this general rule, the legislator has delayed the efficiency of the administrative sanctions to a later moment in the art. 138.3 Law 30/1992 and other similar rules of sectorial laws.

Nevertheless, one of the aims of the Law of reform 18/2009, of November 23, has been that the fines of traffic produce effects and could be executed as soon as possible and it finds disadvantages neither in the presumption of innocence nor in the judicial effective guardianship, but the above mentioned law has done it of a such form that seems to have incurred a flagrant contradiction that, despite everything, can be overcome by means of an of integration and harmonious interpretation of the law.
\end{abstract}

Key words

Administrative procedure, sanctioning Administration, Traffic, Road Security, Efectiveness, Jurisprudence, Spain.

* Grupo de investigación de la Junta de Andalucía SEJ-196. Proyecto del Ministerio de Ciencia e Innovación DER2009-12146. 


\section{LA EFICACIA Y LA EJECUCIÓN DE LOS ACTOS ADMINISTRATIVOS Y SUS PECULIARIDADES EN EL ÁMBITO DE LAS SANCIONES}

El privilegio de autotutela de la Administración se traduce, dicho muy simplemente, en que los actos administrativos obligan directamente y producen efecto desde que se dictan y notifican (autotutela declarativa o ejecutividad) y en que, en caso de incumplimiento voluntario por el interesado, la Administración, cuando el acto le imponga un comportamiento, puede proceder ella misma y por sus propios medios a su ejecución sin necesidad de acudir a un juez (autotutela ejecutiva, ejecutoriedad o ejecución forzosa). Ésta es la regla general que rige en nuestro Derecho para todos los actos administrativos ${ }^{1}$ y así lo ha consagrado la Ley 30/1992, de 26 de noviembre, de Régimen Jurídico de las Administraciones Públicas y del Procedimiento Administrativo Común (en adelante, LRJPAC) en sus arts. 56, 94, 95 y 111². A este respecto, conviene realizar las siguientes aclaraciones con carácter general:

Si los actos administrativos no imponen un comportamiento al administrado no habrá ejecución forzosa, pero sí puede haber actos de ejecución por parte de la Administración, por ejemplo, el pago a un particular de la cantidad reconocida en el acto administrativo, la anotación en un registro, etc. Tiene interés recordar esto para la mera detracción de puntos del carné de conducir aunque, según se desprende de la Ley de Tráfico (Real Decreto Legislativo 339/1990, de 2 de marzo, que aprueba el Texto Articulado de la Ley sobre Tráfico, Circulación de Vehículos a Motor y Seguridad Vial), no así de la jurisprudencia, como luego indicaré, esta medida no tenga carácter sancionador. Pero, también, hay sanciones que dan lugar a esta situación: por ejemplo, la que consiste en publicar la resolución sancionadora o la de amonestación o la inhabilitación para contratar o para ser beneficiario de subvenciones.

Si los actos de la Administración imponen un comportamiento a un sujeto (un dar, un hacer, un no hacer), éste está obligado a realizarlo desde el mismo momento en que se le notifica el acto. Desde luego, esa obligatoriedad depende de la realización correcta de la notificación, con las salvedades derivadas del art. 58.3 LRJPAC y de las posibilidades de que se dé por hecha la notificación aunque no se haya practicado materialmente. En concreto, para las sanciones de tráfico, hay que estar no sólo a lo dispuesto con carácter general sino a lo previsto para las notificaciones en el sector por los nuevos arts. 77 y 78 de la Ley de Tráfico (en adelante, LTSV) 3 .

Desde ese mismo momento de la notificación, se inicia un periodo mal llamado de cumplimiento voluntario -porque no es voluntario, sólo que todavía no se

1 Vid. Luis Martín Rebollo, "Disposiciones administrativas y actos administrativos", La nueva Ley de Régimen Jurídico de las Administraciones Públicas y del Procedimiento Administrativo Común, dirigido por Jesús Leguina Villa y Miguel Sánchez Morón, Tecnos, 1993, Madrid, pp. 165-173.

2 Es conveniente destacar aquí que ni el legislador ni la jurisprudencia utilizan siempre los términos "ejecutividad", "ejecutoriedad" y "ejecución forzosa" de los actos administrativos de una forma adecuada. Yo, en este trabajo, trataré de hacerlo bien, aunque, como se comprenderá, ese uso legal y jurispru-

122 dencial inadecuado dificulte en gran medida esta labor que, con todo, me propongo inicialmente. 
utiliza la fuerza o la coacción- y, transcurrido ese periodo, la Administración puede proceder ya a la ejecución forzosa. Para ello, utilizará alguno de los medios de coacción o coerción del art. 96 LRJPAC: apremio sobre el patrimonio, ejecución subsidiaria, multas coercitivas y compulsión sobre las personas. Pero antes, y una vez transcurrido el plazo de cumplimiento voluntario, la Administración tiene que dictar el apercibimiento a que se refiere el art. 95 LRJPAC. En la vía de apremio, que es el medio de ejecución forzosa procedente para las multas, el apercibimiento aparece como primer trámite. De hecho, según expresa el art. 70.2 Real Decreto 939/2005, de 29 de julio, que aprueba el Reglamento General de Recaudación (en adelante, RGR), el apercibimiento forma parte esencial de la providencia de apremio.

Frente a esta ejecutividad y ejecutoriedad sólo se alza la posibilidad de pedir y conseguir la suspensión del acto en vía de recurso. Si se trata de un recurso administrativo, ello está regulado en el art. 111.2 LRJPAC que, incluso, contempla la posibilidad de obtener la suspensión por silencio administrativo positivo (art. 111.3 LRJPAC). Si se trata de un recurso contencioso-administrativo, la suspensión es una de las posibles medidas cautelares según lo previsto en los arts. 129 y ss. LJCA. Pero, a priori, ni siquiera la petición de suspensión suspende automáticamente la eficacia de la resolución impugnada hasta que se resuelva sobre ella ni impide que se proceda a la ejecución forzosa.

En principio, estas mismas reglas eran aplicables a las sanciones administrativas, incluidas las de tráfico. Por tanto, debían ser cumplidas desde que se notificaban y, si no lo eran en el plazo de cumplimiento voluntario, la Administración podía pasar a la ejecución forzosa, todo ello aunque fueran susceptibles de recurso administrativo (reposición o alzada) o contencioso-administrativo; es decir, aunque no fueran firmes, ni siquiera firmes en vía administrativa, o aunque no agotaran la vía administrativa.

Y la verdad es que todo eso sigue siendo cierto en general, salvo en lo que se refiere al momento para poder hacerlo: en esto se centrará este trabajo.

Pues bien, como dije antes, a pesar de que la regla general sea que los actos administrativos son inmediatamente ejecutivos, en el ámbito del Derecho Administrativo sancionador, sin embargo, el legislador ha optado por otra regla que retrasa la eficacia de las resoluciones sancionadoras, parece que para incrementar las garantías del sancionado ante la imposición de castigos administrativos. Pero no es fácil saber qué es lo que se ha consagrado exactamente; ni tampoco en qué medida esa solución excepcional obedece a la simple y libre voluntad del legislador o es una imposición de la CE; ni, si en ese caso, es una exigencia constitucional que deriva de una garantía propia y exclusiva de las sanciones (del derecho fundamental a la presunción de inocencia) o de todos los actos administrativos en general (del derecho fundamental a la tutela judicial efectiva) y, en consecuencia, puede extenderse más allá del ámbito de la potestad sancionadora de la Administración. 
En esencia, la ejecutividad inmediata de las sanciones administrativas ha planteado dos problemas de constitucionalidad diferentes. Por una parte, su posible colisión con el derecho fundamental a la presunción de inocencia consagrado en el art. 24.2 CE y, en segundo lugar, su incompatibilidad respecto del derecho constitucional a la tutela judicial efectiva del art. 24.1 CE. Si el primero es un asunto exclusivo de las sanciones, el segundo, como se comprobará, puede extenderse a todas las resoluciones administrativas desfavorables para el interesado con carácter general.

\section{LA EJECUTIVIDAD INMEDIATA DE LAS SANCIONES ADMINISTRATIVAS Y LA PRESUNCIÓN DE INOCENCIA}

La aplicación de las reglas generales sobre ejecutividad y ejecutoriedad de los actos administrativos en el ámbito de las sanciones supondría que éstas deben cumplirse desde que se dictan y notifican al interesado y que, de no hacerse así, la Administración, para hacerlas efectivas, podría pasar de inmediato a su ejecución forzosa con independencia de su posible impugnación en vía administrativa o judicial. De hecho -antes lo expliqué-, ésta fue la solución aplicable durante mucho tiempo, pero con la traslación al Derecho Administrativo sancionador por parte del TC de las garantías básicas del proceso penal, sobre todo, de la presunción de inocencia, se puso en tela de juicio esa ejecutividad inmediata de las sanciones. El planteamiento fue el siguiente: si la presunción de inocencia impone que se trate al imputado como inocente en tanto ese derecho fundamental no sea definitivamente enervado ${ }^{4}$, ha de retrasarse la posibilidad de la Administración de exigir su cumplimiento hasta el momento en que la sanción sea confirmada -o pueda serlo- por un juez que es quién tiene la última palabra en el asunto.

Así que la presunción de inocencia conduciría, siguiendo este razonamiento, a que las sanciones administrativas sólo puedan ejecutarse cuando sean completamente firmes y ello supondría para ellas un régimen peculiar de autotutela diferente al del resto de los actos administrativos dónde no resulta aplicable la presunción de inocencia. Una línea jurisprudencial ${ }^{5}$ y un sector de la doctrina ${ }^{6}$ han mantenido esta postura.

4 Vid., sobre la presunción de inocencia como regla de tratamiento del acusado, Lucía Alarcón Sotomayor, El procedimiento administrativo sancionador y los derechos fundamentales, Thomson-Civitas, 2007, Madrid, pp. 451-455.

5 Sobre todo, en el ámbito de las sanciones tributarias (SSTS de 3 de diciembre de 2002, Ar. 866 de 2003; y de 5 de febrero y 5 de octubre de 2004, Ar. 925 y 10 de 2005) pero, también, para las sanciones disciplinarias impuestas a funcionarios (STS de 23 de junio de 1989, Sala Especial de Revisión, Ar. 1577 de 1991; y SSTSJ de la Comunidad Valenciana, de 11 de febrero de 1998, Ar. 356; de Murcia, de 22 de julio de 1998, Ar. 1235; y de Canarias/Las Palmas, de 10 de septiembre de 1999, Ar. 3300).

6 Vid, en esta línea, Alejandro Nieto García, Derecho Administrativo Sancionador, $4 .^{\text {a }}$ edic., Tecnos, 2005, Madrid; p. 417; Eduardo García de Enterría y Tomás-Ramón Fernández Rodríguez, Curso de Derecho Administrativo, vol. II, Civitas, 8. ${ }^{a}$ edic., 2002, Madrid, pp. 182 y 203; Ramón Parada Vázquez, Derecho Admi-

124 nistrativo I. Parte general, vol. I, $7^{a}$ edic., Marcial Pons, 1995, Madrid, p. 529; Francisco González Navarro y 
Sin embargo, como ya expliqué en su momento7, esa teoría no me parece correcta pues parte de un error conceptual, como es que la presunción de inocencia del acusado sólo se destruye cuando se agoten todas las posibilidades de revisión de la resolución sancionadora. Por el contrario, y en mi opinión, la presunción de inocencia se desvirtúa cuando la Administración impone la sanción y no cuando la confirma el juez: es decir, es la prueba incriminatoria obtenida con las debidas garantías en el procedimiento administrativo la que destruye la presunción de inocencia del acusado y justifica la emisión del acto sancionador. A partir de ese momento, y con independencia de su revisión ulterior, ya no hay presunción de inocencia sino prueba de la culpabilidad del sancionado. También hay autores que se han pronunciado en este sentido ${ }^{8}$.

En definitiva, la ejecutividad inmediata de las sanciones no se opone a la presunción de inocencia o, dicho de otra forma, la presunción de inocencia no impone la alteración de las reglas generales sobre la eficacia y la ejecución forzosa de los actos administrativos en materia de sanciones.

Ésta es, además, la solución que ha proclamado el TC, tras algunos titubeos del TS en el ámbito tributario ${ }^{9}$ que deben entenderse abandonados y superados por la más reciente y actual jurisprudencia. Ya dijo la STC 66/1984, de 6 de junio, que

\begin{abstract}
"la efectividad de las sanciones no entra en colisión con la presunción de inocencia; la propia legitimidad de la potestad sancionadora y la sujeción a un procedimiento contradictorio, abierto al juego de la prueba, (...) excluye toda idea de confrontación de la presunción de inocencia con la inmediata ejecutividad de las sanciones".
\end{abstract}

Y, más recientemente, la Sala Tercera del TS viene declarando que "la ejecutividad de los actos administrativos sancionadores (...) no contraría a la presunción de inocencia" (SSTS de 18 de septiembre y 19 de diciembre de 2001, Ars. 430 de 2002 y 10119; de 4 de febrero de 2002, Ar. 1084; y de 5 de febrero de 2004, Ar. 925).

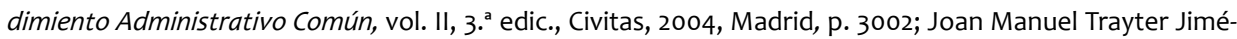
nez y Vicenç Aguado i Cudolà, Derecho Administrativo Sancionador: Materiales, Cedecs, 1995, Barcelona, p. 196; Federico A. Castillo Blanco, Función pública y poder disciplinario del Estado, CEMCI, 1992, Granada, p. 496; y María Rubio de Casas, "De nuevo sobre la potestad sancionatoria: la sentencia del Tribunal Constitucional de 6 de junio de 1984 ", REDA, n. ${ }^{\circ} 42$, abril-junio de 1984, p. 481.

7 Lucía Alarcón Sotomayor, El procedimiento administrativo sancionador y los derechos fundamentales, op. cit., pp. 469-474.

8 Javier Barcelona Llop, Ejecutividad, ejecutoriedad y ejecución forzosa de los actos administrativos, Servicio de Publicaciones de la Universidad de Cantabria, 1998, Santander, p. 434; Ignacio Díez-Picazo Giménez, "Artículo 24. Garantías procesales", Comentarios a la Constitución Española de 1978, dirigidos por Óscar Alzaga Villaamil, vol. III, Edersa, 1996, Madrid, p. 120; José Garberí Llobregat y Guadalupe Buitrón Ramírez, El procedimiento administrativo sancionador, vol. I, 4. ${ }^{a}$ edic., Tirant lo Blanch, 2001, Valencia, p. 425; y Belén Marina Jalvo, El Régimen disciplinario de los funcionarios públicos, Lex Nova, 1999, Valladolid, p. 290.

9 Vid. SSTS de 3 de diciembre de 2002, Ar. 866 de 2003; y de 5 de febrero y 5 de octubre de 2004, Ars. 925 y 10 de 2005 . 
Así que la competencia para establecer si las sanciones son ejecutivas desde que se dictan, cuando causen estado, desde que sean firmes en vía administrativa o cuando las revise el juez no influye en el art. 24.2 CE. Se consagra así que ese "margen de libre actuación del legislador (...), en nada afecta a la presunción de inocencia" (SSTS de 13 de febrero de 1998, Ar. 2183; de 20 de octubre de 1999, Ar. 4320 de 2000; y de 27 de marzo de 2000, Ar. 3800).

\section{LAS PREVISIONES DEL LEGISLADOR SOBRE LA EJECUCIÓN DE LAS SANCIONES}

\section{Planteamiento}

Aunque la presunción de inocencia no impide la ejecutividad inmediata de las sanciones, el legislador, lo dije al principio, ha optado por retrasarla -con excepciones, sobre todo, en el ámbito disciplinario ${ }^{10}$ - con el fin de incrementar las garantías del sancionado. $Y$ lo ha hecho tanto para las sanciones administrativas con carácter general como para las sanciones de tráfico en particular. Para ello, ha utilizado fórmulas heterogéneas, unas más acertadas y otras menos, que, en esencia, quieren significar que las sanciones sólo serán ejecutivas cuando constituyan la última palabra de la Administración. Me referiré primero a la regulación estatal general y, luego, me centraré en la normativa de tráfico.

\section{La ejecutividad de las sanciones en el art. 138.3 LRJPAC}

El art. 138.3 LRJPAC se aparta así de la regla general: "la resolución (sancionadora) será ejecutiva cuando ponga fin a la vía administrativa”. Sensu contrario, la resolución que no ponga fin a la vía administrativa no será ejecutiva.

Aunque es evidente que esta regla pospone la eficacia de las sanciones, no resulta tan claro cuál es el momento exacto al que se posterga esa ejecutividad. Y ello porque la redacción del precepto no es técnicamente correcta y se ha quedado anticuada. Parece que el objetivo del legislador es retrasar la posibilidad de exigir su cumplimiento hasta el momento en que las sanciones se conviertan en irrecurribles ante la propia Administración, pero lo ha hecho muy mal porque 'poner fin a la vía adminis-

10 Por ejemplo, en el art. 67 de la Ley 8/1998, de 2 de diciembre, de Régimen Disciplinario de las Fuerzas Armadas: “Las sanciones disciplinarias serán inmediatamente ejecutivas y comenzarán a cumplirse el mismo día en que se notifique al infractor la resolución por la que se imponen (...). Se exceptúa el caso en que se hubiera acordado la suspensión de la sanción de privación de libertad, durante el tiempo de tramitación del recurso que se interponga”. Y, también, en el art. 66 de la Ley 17/2007, de 22 de octubre, de Régimen Disciplinario de la Guardia Civil: “1. Las sanciones impuestas serán inmediatamente ejecutivas, no suspendiendo su cumplimiento la interposición de ningún tipo de recurso, administrativo o judicial. 2. Las 126 le imponen, si en ésta no se dispusiera, motivadamente, lo contrario". 
trativa' no quiere decir eso. De hecho, la fórmula legal que refleja mejor esta idea es la de firmeza en vía administrativa, que es, precisamente, el concepto que maneja la legislación de tráfico con carácter general. Así pues 'poner fin a la vía administrativa' y 'firmeza en vía administrativa' significan cosas distintas. Creo que conviene aclararlo mejor.

Por un lado, una sanción es firme en vía administrativa cuando no es susceptible de recurso administrativo ordinario: ni de alzada ni de reposición ${ }^{11}$, bien porque sea originariamente irrecurrible ante la Administración, bien porque ya se haya interpuesto contra ella y resuelto el recurso administrativo procedente, bien porque aunque sea susceptible del mismo se haya dejado transcurrir el plazo de impugnación sin hacerlo.

Por el otro lado, pone fin, agota la vía administrativa o causa estado la sanción que sea susceptible directamente de recurso contencioso-administrativo o que no lo sea del administrativo de alzada, bien porque haya sido dictada por un órgano sin superior jerárquico, bien porque lo diga expresamente una ley, bien porque se trate propiamente de la resolución de un recurso de alzada interpuesto anteriormente (art. 109 LRJPAC). De esta forma, las resoluciones que no ponen fin a la vía administrativa son las que todavía no se pueden impugnar ante la jurisdicción contenciosoadministrativa sino que antes han de ser recurridas en alzada.

Pues bien, tal y como exige el 138.3 LRJPAC, hace falta que la sanción agote la vía administrativa para que se convierta en ejecutiva. Esto plantea el inconveniente de que si una sanción es susceptible de recurso de alzada pero no se recurre nunca llegará a poner fin a la vía administrativa aunque el transcurso del plazo sin impugnación la convierta en firme (art. 115.1, párrafo tercero, LRJPAC). Es decir, habría sanciones ineficaces o no ejecutivas según lo dispuesto en el art. 138.3 LRJPAC.

El legislador se dio cuenta de esto y en el art. 21 Real Decreto 1398/1993, de 4 de agosto, que aprueba el Reglamento del Procedimiento para el ejercicio de la Potestad Sancionadora (en adelante, RPS) trató de corregir su error. El precepto en cuestión dice así:

1. "Las resoluciones que pongan fin a la vía administrativa serán inmediatamente ejecutivas y contra las mismas no podrá interponerse recurso administrativo ordinario.

2. Las resoluciones que no pongan fin a la vía administrativa no serán ejecutivas en tanto no haya recaído resolución del recurso ordinario que, en su caso, se

11 La posibilidad de interponer un recurso administrativo de revisión, que es de carácter extraordinario, no supone ningún impedimento para la firmeza en vía administrativa de la sanción. De hecho, el art. 108 y el art. 118.1 LRJPAC disponen que este recurso procede contras las resoluciones firmes en vía administrativa. 
haya interpuesto o haya transcurrido el plazo para su interposición sin que ésta se haya producido".

Con este precepto, ya sí se puede hacer una interpretación correctora del art. 138.3 LRJPAC y declarar la ejecutividad de las sanciones que no causen estado pero que sean firmes por haber transcurrido el plazo de interposición del recurso de alzada sin que se haya recurrido.

Aun así, el 138.3 se ha oscurecido después todavía más, cuando la Ley 4/1999, de 13 de enero, introdujo de nuevo el recurso administrativo de reposición en los arts. 116 y 117 LRJPAC. Estos preceptos lo regulan como un recurso potestativo y susceptible de interposición contra las resoluciones que pongan fin a la vía administrativa antes de ser impugnadas en vía judicial. El problema es que la Ley 4/1999 de reforma de la LRJPAC no tocó el art. 138.3. Así que, según el tenor literal de este precepto, las sanciones que pongan fin a la vía administrativa serán ejecutivas inmediatamente con independencia de que decidan impugnarse o no en reposición o en vía judicial. Es decir, que la interposición de un recurso de reposición -o el mes que es necesario que pase para que la sanción se convierta en firme en vía administrativa si no se recurre- no suspende su eficacia, a menos que la suspensión se pida y se acuerde expresamente.

No obstante, parece que, aunque la letra del precepto imponga esta solución, lo más razonable es realizar una interpretación correctora e integradora con los arts 116 y 117 LRJPAC y considerar que el legislador, a partir de 1999, también ha querido incluir en el art. 138.3 al recurso de reposición y a sus posibles consecuencias sobre la ejecutividad de las sanciones. Y ello porque es una regla absolutamente irracional y arbitraria hacer depender la ejecutividad de las sanciones de que agoten o no la vía administrativa.

De conformidad con esa interpretación conciliadora del art. 138.3 LRJPAC, las sanciones que causen estado no serán inmediatamente ejecutivas sino sólo desde el momento en que adquieran firmeza en vía administrativa: cosa que ocurrirá cuando se dicte resolución del recurso de reposición en su contra o cuando haya transcurrido el plazo de un mes sin su interposición. Pero, insisto, en rigor, y si se atiende únicamente al tenor literal del precepto, la posibilidad de interponer un recurso administrativo de reposición contra la sanción (o un recurso contencioso-administrativo, como luego se verá), no así un recurso de alzada, no suspende su ejecutividad.

Ante esta incertidumbre, parece que sería bueno realizar una reforma del desafortunado 138.3 LRJPAC en este sentido, que proclame como primera medida -y con independencia de que la jurisprudencia del TC le obligue a decir más cosas, como después se verá- que las sanciones no son ejecutivas mientras siga abierta la vía administrativa. Una posible fórmula sería decir que puede exigirse su cumplimiento desde su firmeza en esta vía, esto es, cuando ya no sean susceptibles ni de recurso de alzada (por provenir de un órgano administrativo sin superior jerárquico, por haberse inter128 puesto y resuelto tal recurso o por haber pasado su plazo de interposición sin impug- 
nación) ni de recurso de reposición (por haberse formulado y resuelto, por haber expirado el plazo para su interposición o por haber impugnado directamente la sanción en vía contencioso-administrativa sin petición de suspensión cautelar). La posibilidad de interponer cualquiera de los dos, no así uno judicial, paralizaría su ejecutividad.

De hecho, ésta es la solución que parece haber acogido la Ley de Tráfico para la eficacia de las multas tras su última reforma. Es decir, lo cierto y lo que parece haber tenido en cuenta la Ley 18/2009, de 23 de noviembre, de reforma de la Ley de Tráfico (en adelante, LTSV) es que el art. 138.3 LRJPAC quiere decir lo que no dice. Trataré de explicarlo.

\section{La eficacia y la ejecución de las sanciones de tráfico tras la Ley 18/2009, de 23 de noviembre, de reforma de la LTSV}

\section{A) Aproximación}

Uno de los objetivos esenciales de la Ley de reforma 18/2009, de 23 de noviembre, ha sido que las sanciones de tráfico produzcan efectos y puedan ejecutarse cuanto antes. Este deseo es muy compresible y, como ya expliqué, no encuentra inconvenientes en la presunción de inocencia; pero la Ley 18/2009 lo ha hecho de una forma tal que parece haber incurrido en una contradicción flagrante. Así, como de inmediato expondré, en una serie de artículos -destacadamente, el nuevo art. 82 LTSV- se dice que las sanciones podrán ejecutarse desde el día siguiente a aquél en que se notifiquen. Y ello es así porque ponen fin a la vía administrativa y sólo cabe impugnarlas, de entre los recursos administrativos, mediante el de reposición, del que se dice "no suspende la ejecución (...) de la sanción". Con todo, al menos hay que aceptar que el legislador en esos preceptos no quiere decir realmente que se pueda pasar a la ejecución forzosa al día siguiente de su notificación pues, como mínimo, tiene que dejarse un plazo de cumplimiento voluntario, que parece encontrase en los quince días naturales del art. 90 LTSV. En suma, hay que interpretar que esos preceptos vuelven a la inmediata ejecutividad de las sanciones, pero no y a pesar de su defectuosa redacción a la ejecución forzosa inmediata, lo que ya sería excesivo.

Pero, en otros artículos de la Ley 18/2009, precisamente, los que aparecen en el Capítulo de la LTSV dedicado a la "Ejecución de las sanciones" (arts. 88, 89 y 90), se establece que las sanciones podrán ejecutarse cuando alcancen firmeza en vía administrativa o al mes o a los quince días naturales de lograrlo. Esto, evidentemente, no es lo mismo que lo anterior porque, en tanto quepa interponer recurso de reposición, no hay firmeza en vía administrativa y, si se interpone, no la hay hasta que se resuelva.

Ante esta contradicción, el problema esencial que se plantea, además del de realizar unas labores de interpretación del tenor literal de esos artículos que resultan endemoniadas, es que habrá que pensar cuáles de todos esos son los preceptos equivocados y cuáles, por contra, los que imponen la solución correcta. 


\section{B) La solución general del nuevo art. 88 LTSV. Su complemento en los arts. 89 y 90}

El nuevo texto de la LTSV tras la reforma operada por la Ley 18/2009, de 23 de noviembre, le dedica a este tema el Capítulo V del Título V (Régimen Sancionador) que se denomina "Ejecución de las Sanciones". Sobre todo, son interesantes el art. 88 y el art. 90. El primero de ellos dispone:

\section{Artículo 88. Ejecución de las sanciones.-}

"Una vez firmes en vía administrativa, se podrá proceder a la ejecución de las sanciones conforme a lo previsto en esta Ley".

El art. 88 LTSV consagra, como regla general, la ejecutividad de las sanciones de tráfico desde su firmeza en vía administrativa. Se plasma así mucho más correctamente la regla que, pese a todo, ha de considerarse latente en el art. 138.3 LRJPAC. Ésta es, además, casi la misma fórmula que han usado otras Leyes administrativas como, por ejemplo, el art. 38.1 Ley Orgánica 1/1992, de 21 de febrero, de Protección de la Seguridad Ciudadana, el art. 212.3 Ley 58/2003, de 17 de diciembre, General Tributaria y el art. 43.5 de la Ley Vasca 2/1998, de 20 de febrero, de la Potestad Sancionadora de las Administraciones Públicas.

A esto hay que añadir una singularidad importante y es que la resolución del procedimiento sancionador en materia de tráfico pone fin a la vía administrativa. Así lo dispone la LTSV para la resolución de los dos tipos de procedimientos sancionadores que regula. El art. 80 d) LTSV lo dice para la resolución del procedimiento sancionador abreviado y art. 82.1 LTSV para la del procedimiento sancionador ordinario. Con ello, resulta que la nueva LTSV ha decidido suprimir en bloque y sin excepción el recurso administrativo de alzada para impugnar las sanciones de tráfico y sólo ha dejado vigente, como único medio de impugnación en vía administrativa, el recurso de reposición. Aunque, en realidad, ni siquiera ha mantenido la reposición con carácter general, puesto que la excluye expresamente del nuevo procedimiento sancionador abreviado [art. 80 d) LTSV]. El resultado, por tanto, es que el recurso de reposición únicamente resulta aplicable para impugnar las sanciones impuestas tras la tramitación del procedimiento sancionador ordinario [art. 82.2 LTSV]. Insistiré en esto.

El procedimiento sancionador abreviado es el que procede tramitar cuando el acusado decide pagar voluntariamente la multa, con el respectivo descuento, dentro del plazo de quince días naturales desde el siguiente a la notificación de la denuncia (en el acto de su formulación por los agentes o en la DEV o el domicilio del imputado), según dispone el art. 80 LTSV. Aunque la resolución sancionadora en estos casos no plantee problemas de ejecución, pues el abreviado es el procedimiento aplicable en caso de pago voluntario -cuando la multa ya está pagada-, y aunque sea incongruente plantearse su suspensión en vía de recurso judicial, sí conviene resaltar sus diferencias con relación al ordinario y tener en cuenta que sí es relevante, en todo caso, la

130 posibilidad o no de impugnación posterior de la sanción ya satisfecha. Pues bien, el 
pago voluntario en este procedimiento origina su terminación sin necesidad de dictar resolución sancionadora expresa. Esta resolución ficticia que, en realidad, es la propia denuncia (o el acto de incoación) y que se tiene por emitida el día del pago agota la vía administrativa y no es susceptible más que de recurso contencioso-administrativo. No cabe, por tanto, ningún recurso administrativo en su contra: ni de alzada [art. 80 d) LTSV] ni de reposición. El art. 80 f) LTSV lo expresa diciendo que en el procedimiento sancionador abreviado se produce "la firmeza de la sanción en la vía administrativa desde el momento del pago (voluntario), produciendo plenos efectos desde el día siguiente". Así que, para estos casos, el legislador prevé que la denuncia de tráfico se convierta, sin más y directamente, en resolución sancionadora firme en vía administrativa.

El problema de la ejecución forzosa de las sanciones de tráfico se plantea verdaderamente en el procedimiento sancionador ordinario, que es el tradicional -aunque con importantes novedades- y el que procede tramitar cuando el imputado no paga voluntariamente (art. $81 \mathrm{LTSV}$ ). Pues bien, la resolución del procedimiento ordinario que, como luego explicaré, puede ser expresa (art. 81 y art. 82 LTSV) o ficticia (art. 81.5 LTSV), dependiendo de si el acusado decide alegar o no en contra de la denuncia o el acto de iniciación, también pone fin a la vía administrativa y, ahora sí, es susceptible o de recurso administrativo de reposición (art. 82.2 LTSV) o directamente de recurso contencioso-administrativo. En estos casos, según establece el art. 88 LTSV, y teniendo siempre presente que se ha eliminado la alzada, la sanción sólo podrá ejecutarse forzosamente o bien cuando haya transcurrido el plazo de un mes de interposición del recurso de reposición sin impugnación o bien cuando se haya dictado resolución del mismo. Será entonces, según las previsiones del art. 88 LTSV y aunque siga abierto el plazo de interposición del recurso contencioso-administrativo o éste ya se haya planteado, cuando la resolución sancionadora se convierta en firme en vía administrativa.

La regla sería ésta sin más complicación si la LTSV no hubiera añadido nada más al respecto: la alzada está prohibida y la Administración puede proceder a la ejecución forzosa de las multas de tráfico que imponga cuando se cierre la vía administrativa -cuando ya no quepa la reposición-, aunque se haya interpuesto el recurso contencioso-administrativo o esté abierto el plazo para ello.

De hecho, ésta habría sido la mejor solución, pero parece que el legislador no se quedó satisfecho con una regulación tan escueta y quiso perfeccionarla y desarrollarla. El problema es que lo ha hecho tan mal que los demás preceptos que se ocupan de este tema sólo lo enredan y lo complican todo. En concreto, esa regulación adicional sobre la ejecución de las sanciones de tráfico se encuentra en nada menos que cuatro preceptos más de la LTSV: el art. 90, el art. 89, el art. 82.1 y 3, y el art. 81.5.

Los dos primeros -art. 89 y art. 90- tratan de completar la regla general del art. 88 LTSV para las dos clases de sanciones previstas en la LTSV: el art. 88 lo hace para las sanciones de suspensión de autorizaciones y el art. 90 para las sanciones pecunia- 
rias. Sin embargo, los dos últimos -el art. 82.1 y 3 y el art. 81.5-, como anticipé, parecen establecer dos reglas especiales sobre la ejecución pero no se sabe bien en qué consisten y, además, están mal formuladas.

Empezaré por el art. 90 LTSV que se refiere a la ejecutividad de las multas. Hay que decir que la multa se ha convertido, ahora más que nunca y tras la supresión por la Ley de reforma de la sanción de suspensión temporal del permiso de conducción, en la sanción de tráfico por excelencia ${ }^{12}$. Con relación a esto, importa señalar que la LTSV no consagra -ni en el art. 65 ni en ningún otro- el carácter punitivo de la pérdida parcial de puntos del carné de conducir, que lleva aparejada la sanción de multa por la comisión de algunas de las infracciones tipificadas en la LTSV. A pesar de ello, la jurisprudencia sí ha declarado recientemente su naturaleza sancionadora ${ }^{13}$ con todo lo que ello conlleva y puede suponer en el futuro ${ }^{14}$.

Pues bien, y retomando la cuestión, al art. 90 LTSV parece remitirse el art. 88 cuando señala que las sanciones, una vez firmes en vía administrativa, podrán ejecutarse "conforme a lo previsto en esta Ley".

Artículo 90. Cobro de las multas.-

1. "Las multas que no hayan sido abonadas durante el procedimiento deberán hacerse efectivas dentro de los quince días naturales siguientes a la fecha de la firmeza de la sanción.

2. Vencido el plazo de ingreso establecido en el apartado anterior sin que se hubiese satisfecho la multa, su exacción se llevará a cabo por el procedimiento de apremio (...)".

La lectura de este precepto causa un cierto desasosiego. Ahora, resulta, al revés del art. 88, que las multas sólo se convierten en ejecutivas a los quince días -natura-

12 Hay otras pero están previstas para sujetos responsables especiales diferentes al conductor del vehículo: por ejemplo, el art. 67.2, párrafo segundo, LTSV prevé la sanción de suspensión de la autorización del funcionamiento de autoescuelas.

13 Lo acaba de afirmar la STS de 4 de junio de 2009, recurso de casación 25/2006, en el mismo sentido de la STC 63/2007: "la pérdida de puntos es una consecuencia directa y automática de la sanción, y participa de su misma naturaleza”. De este modo, "pese a que la pérdida de puntos no aparece incluida en el catálogo de sanciones del artículo 67 del Texto Articulado (...), es indudable que la pérdida de puntos es una medida que tiene carácter materialmente sancionador. El que el descuento de los puntos no se haga efectivo sino cuando la sanción es firme no viene sino a confirmar la naturaleza sancionadora de la pérdida de puntos, pues es también después de la firmeza cuando se produce la anotación de sanción en el Registro de conductores e infractores". Como consecuencia de la naturaleza sancionadora de esta medida, la sentencia sugiere la posibilidad de que su imposición pueda ser combatida, en su caso, mediante el recurso de amparo y el contencioso-administrativo especial para la protección de los derechos fundamentales de la persona.

14 Vid., al respecto, Tomás Cano Campos, El régimen jurídico administrativo del tráfico, ThomsonCivitas, $2^{\text {a }}$ edic., 2010, Madrid, 498-503; y “Tráfico: infracciones y sanciones", Diccionario de Sanciones Administrativas, dirigido por Blanca Lozano Cutanda, lustel, 2010, Madrid (en prensa). Vid., también, en este mismo número, Miguel Casino Rubio, “La naturaleza jurídica de la pérdida de puntos". 
les- de adquirir firmeza a secas y no de hacerlo en vía administrativa. A este respecto, interesa destacar que una cosa es que una resolución sea firme sin más, esto es, no susceptible de recurso ordinario: ni administrativo ni judicial; y otra cosa es que sea firme en la vía administrativa: no impugnable mediante recurso administrativo ordinario pero sí contencioso-administrativo.

Parece, por tanto, que el legislador ha retrasado aquí -en el art. 90-, para las sanciones pecuniarias, el momento en que puede exigirse su cumplimiento. Para ellas, en el caso, claro está, de que no hayan sido pagadas voluntariamente durante el procedimiento abreviado, el art. 90 LTSV establece un plazo de quince días naturales de cumplimiento voluntario que computa desde su firmeza: en las vías judicial y administrativa. Y será firme la multa contra la que ya no quepa interponer recurso judicial: o bien porque haya transcurrido el plazo de interposición sin recurrir o bien porque ya se haya interpuesto y dictado sentencia que confirme la sanción. Como puede comprobarse, la solución que ofrecen los arts 88 y 90 por separado es distinta y sus diferencias se hacen especialmente intensas en el caso de que el sancionado decida interponer el recurso contencioso-administrativo pues, según lo previsto en el primero, el recurso judicial no suspende la ejecutividad de la multa impugnada, mientras que, si se aplica lo que dice el segundo, sí paraliza su eficacia.

Es posible que el legislador se haya equivocado al redactar el art. 90 LTSV, es decir, que este precepto quiera reflejar lo mismo que el art. 88 pero lo haya hecho con una redacción errónea o, incluso, más corta con la intención de abreviar, pero si se está a lo que literalmente dice no se pueden ejecutar forzosamente las multas hasta que no hayan pasado quince días naturales desde que adquieran firmeza ante los Tribunales. No obstante, pese a todo, y aunque resulta muy criticable que el legislador se haya querido ahorrar un par de palabras en un tema tan delicado -y en el que, precisamente, tres palabras más o menos imponen una solución o la contraria-, parece que hay que superar y abandonar esa interpretación literal y que es más adecuado al conjunto del Capítulo V de la LTSV realizar una interpretación global de los arts. 88 y 90: esto supondría sostener la ejecutividad de las multas de tráfico desde los quince días naturales de su firmeza en la vía administrativa. Así debe ser en mi opinión, aunque esta solución, como luego se verá, plantee ciertos problemas de constitucionalidad según la jurisprudencia del TC al respecto.

Por su parte, el art. 89 LTSV también completa la regla general del art. 88, ahora, con relación a las sanciones de suspensión de las autorizaciones previstas en la LTSV, por ejemplo, para el funcionamiento de autoescuelas (art. 67.2, párrafo segundo). En él se regula:

“El cumplimiento de la sanción de suspensión de las autorizaciones reguladas en esta Ley se iniciará transcurrido un mes desde que la sanción haya adquirido firmeza en vía administrativa y el periodo de suspensión de las mismas se anotará en los correspondientes Registros". 
Esta vez el legislador lo hace bien: puede procederse a la ejecución forzosa de esa sanción al mes (plazo de cumplimiento voluntario) de su firmeza en vía administrativa, tal y como prevé el art. 88 LTSV con carácter general.

\section{C) Las reglas especiales del art. 82 y del art. 81.5 LTSV}

\section{a) La supuesta regla especial del art. 82.1 y 3 LTSV}

El nuevo art. 82 LTSV regula la resolución y los recursos administrativos procedentes para impugnarla en el procedimiento sancionador ordinario. Éste es el procedimiento general y el que procede tramitar cuando el acusado no quiera pagar la multa voluntariamente. Teniendo esto en cuenta, lo lógico es pensar que los arts. 88 y 90 LTSV se han redactado, precisamente, para regular la ejecución de las multas que se dicten en este procedimiento. Pero parece que no es así si uno repara en los apartados 1 y 3 del art. 82:

Artículo 82. Recursos en el procedimiento sancionador ordinario.-

1. “La resolución sancionadora pondrá fin a la vía administrativa y la sanción se podrá ejecutar desde el día siguiente a aquél en que se notifique al interesado, produciendo plenos efectos ...

\section{(...)}

3. La interposición del recurso de reposición no suspenderá la ejecución del acto impugnado ni de la sanción. En el caso de que el recurrente solicite la suspensión de la ejecución, ésta se entenderá denegada transcurrido el plazo de un mes desde la solicitud sin que se haya resuelto".

La lectura de este artículo causa una gran inquietud. Frente al art. 88 LTSV, que retrasa la ejecutividad de las sanciones de tráfico a cuando sean firmes en vía administrativa, el art. 82.1 la adelanta al momento en que se dicten y notifiquen al sancionado. En consecuencia, y en contra de la solución del art. 88, la posibilidad de interponer un recurso administrativo de reposición contra la sanción no suspende su ejecutividad. Así lo declara expresamente el propio art. 82.3 que establece, incluso, una regla inversa a la dispuesta en el art. 111.3 LRJPAC, consistente en la desestimación por silencio de la solicitud de suspensión de la sanción que se haya impugnado en reposición. Se consagra aquí, por tanto, para las sanciones de tráfico, la regla general sobre la ejecución forzosa de los actos administrativos, según la cual la Administración puede exigir su cumplimiento desde que los notifica -se entiende que después del plazo de cumplimiento voluntario- y proceder a hacerlos efectivos con carácter inmediato con independencia de su posible impugnación en vía administrativa o contencioso-administrativa. Como dije antes, esta

134 misma solución se ha consagrado, también, en algunas normas sobre régimen dis- 
ciplinario $^{15} . \mathrm{Y}$, como después plantearé, cabe dudar de su constitucionalidad aunque, en rigor, se ajuste a la literalidad del art. 138.3 LRJPAC porque, como se niega la posibilidad de recurso de alzada, la resolución sancionadora en estos casos agota la vía administrativa.

\section{b) La regla especial del 81.5 LTSV}

El art. 81.5 LTSV regula una modalidad especial del procedimiento sancionador ordinario sólo aplicable para algunos tipos de infracciones concretas ${ }^{16}$. Pues bien, también él se ha atrevido con el tema de la ejecutoriedad. Dice lo siguiente:

"Si el denunciado no formula alegaciones ni abona el importe de la multa en el plazo de quince días naturales siguientes al de la notificación de la denuncia, esta surtirá el efecto de acto resolutorio del procedimiento sancionador. En este supuesto, la sanción podrá ejecutarse transcurridos treinta días naturales desde la notificación de la denuncia (...)".

La lectura de este precepto provoca una profunda incertidumbre. Porque, después de analizar lo dispuesto en él y en todos los anteriores, no se encuentra una solución segura y coherente en la LTSV sobre cuándo pueden ejecutarse forzosamente las sanciones de tráfico.

El supuesto que contempla el art. 81.5 es el siguiente. En el caso de que el acusado no pague voluntariamente ni realice alegaciones en el plazo de quince días naturales desde la notificación de la denuncia (en el acto de su formulación o en la DEV o el domicilio), hay que entender que el procedimiento termina al día siguiente (el día decimosexto), según prevé el art. 74.3 e) LTSV. En este caso, dice el art. 81.5 LTSV, la denuncia surte el efecto de resolución sancionadora -sin propuesta de resolución y sin audiencia posterior-y la sanción que se imponga -la prevista en la denuncia- puede ejecutarse a los quince días naturales de la terminación ficticia del procedimiento o, lo que es igual, a los treinta naturales de la notificación de la denuncia. Lo que no sé, porque el art. 81.5 no lo aclara, es si esa resolución ficticia ha de notificarse al sancionado. Pero parece que la intención del legislador es que no sea así, aunque hay que matizar que esto sólo será válido si se le informa convenientemente cuando se le notifique la denuncia de todas las consecuencias y efectos que conlleva la no presentación de alegaciones en su contra (es decir, hay que informarle, como mínimo, de todos los extremos del art. 81.5 LTSV).

15 Así, en el art. 66 de la Ley 17/2007, de 22 de octubre, de Régimen Disciplinario de la Guardia Civil y en el art. 67 de la Ley 8/1998, de 2 de diciembre, de Régimen Disciplinario de las Fuerzas Armadas.

16 Según el propio art. 81.5, párrafo segundo, LTSV, lo previsto en el párrafo primero sólo procede, en su caso, en tres supuestos: en primer lugar, para las infracciones leves; en segundo término, para las infracciones graves que no detraigan puntos; y, en tercer lugar, para las infracciones muy graves o graves siempre que su denuncia se notifique en el acto. 
Por tanto, y según el art. 81.5 LTSV, la Administración puede iniciar el procedimiento de apremio para cobrarse la multa a los treinta días naturales de notificar la denuncia si el imputado no presenta alegaciones o propone o aporta prueba (art. 81.1 LTSV). La regla sería la ejecutividad inmediata de una sanción ficticia o que no ha llegado a dictarse y que proviene de una denuncia que, por expreso deseo del legislador, se transforma en resolución sancionadora que pone fin a la vía administrativa (art. 81.5, párrafo tercero, LTSV). Esta resolución ficticia, como digo, se convierte en ejecutiva a los quince días naturales de la terminación ficticia del procedimiento (que sería el plazo de cumplimiento voluntario) y antes de convertirse en firme en vía administrativa. Por lo que, según se infiere del art. 81.5, párrafos primero y tercero, LTSV, su impugnación en reposición, que se mantiene para este supuesto, no paraliza la eficacia de la multa recurrida, al igual que lo previsto en el art. 82.1 y 3 LTSV para el procedimiento sancionador ordinario con alegaciones y al contrario de la regla general del art. 88 LTSV.

\section{LA REGLA GENERAL DE LA EJECUTIVIDAD DESDE LA FIRMEZA EN VÍA ADMINISTRATIVA PARA TODAS LAS SANCIONES DE TRÁFICO}

Así pues, en la LTSV, hay varias reglas contradictorias sobre el momento en que la Administración puede proceder a la ejecución de las sanciones. Una regla general en el art. 88 que la proclama cuando sean firmes en vía administrativa y dos reglas especiales que la anticipan y que consagran, en el sector del tráfico, la misma solución aplicable para todos los actos administrativos: la posibilidad de proceder a la ejecución forzosa con independencia de su impugnación en vía administrativa (mediante el recurso de reposición, no del de alzada que está excluido de la actual LTSV) o en vía judicial (a través del recurso contencioso-administrativo). No obstante, no creo que la del art. 82.1 LTSV sea, en verdad, una regla de carácter especial puesto que su ámbito de aplicación coincide con el de la regla del art. 88 LTSV. Es decir, parece que más bien se trata de otra regla general: contraria a la prevista en el 88 LTSV.

Conforme a esas reglas supuestamente especiales, la ejecutividad procede o bien desde el día siguiente a aquél en que la sanción expresa se notifique al interesado, si se trata de un procedimiento sancionador ordinario en el que se formulen alegaciones (art. 82.1 LTSV); o bien a los treinta días naturales de la notificación de la denuncia, si se trata de un procedimiento sancionador ordinario en el que el imputado decida no alegar (art. 81.5 LTSV).

Por lo que se refiere a la otra modalidad procedimental que prevé la LTSV -al procedimiento sancionador abreviado del art. 80-, su resolución no plantea problemas de ejecución forzosa porque ese procedimiento sólo resulta aplicable si el acusado paga voluntariamente la multa en el plazo indicado -veinte días naturales según el art. 73.3 d) LTSV o quince días naturales según los arts. 79, 80 y 81 LTSV-.

Como se comprueba, la mezcla de todos esos preceptos y de sus respectivas

136 soluciones origina una inseguridad y unas contradicciones notorias. A mi modo de 
ver, la mejor solución es defender la aplicación de la regla de los arts. 88 y 90 -la posibilidad de apremio desde los quince días naturales de la firmeza en vía administrativa- para todas las multas de tráfico con carácter general, que es la que mejor combina con la doctrina del TC en la materia, que ahora se analizará, y, así pues, ignorar esas otras previsiones legales especiales que no son tales y que se oponen más frontalmente a la jurisprudencia más actual en cuanto adelantan la ejecutividad y disminuyen las garantías del sancionado ${ }^{17}$.

\section{EL RECURSO ADMINISTRATIVO DE REPOSICIÓN Y LA SUSPENSIÓN AUTOMÁTICA DE LAS SANCIONES DE TRÁFICO}

De esa regla general -la ejecutividad de la sanción una vez que alcanza firmeza en vía administrativa-, y a pesar de lo previsto en el art. 82.3 LTSV, deriva otra de forma natural, consistente en que la mera interposición del recurso de reposición tiene efectos suspensivos de la sanción que no puede ejecutarse hasta que se resuelva el recurso. Por tanto, resulta inaplicable la regla del art. 111 LRJPAC: porque el recurso de reposición contra las multas de tráfico produce ope legis, sin necesidad de petición ni de acuerdo, la suspensión automática ${ }^{18}$.

\section{LA EJECUTIVIDAD DE LAS SANCIONES DE TRÁFICO Y LA RESOLUCIÓN EXPRESA DEL RECURSO DE REPOSICIÓN}

Pero no es sólo que la impugnación de la sanción en reposición suspenda la posibilidad de exigir su cumplimiento. Es que, además, esa suspensión se mantiene hasta la resolución expresa de dicho recurso. Por lo siguiente.

Después de una etapa de transición en la que se debatió y polemizó sobre esta cuestión, parece ya claro que el simple silencio negativo no puede equipararse, a efectos de que las sanciones en general y las de tráfico en particular alcancen firmeza en vía administrativa, a una resolución expresa desestimatoria del recurso ${ }^{19}$.

Ésta es la interpretación que se desprende del art. 21.2 RPS cuando dice que las resoluciones sancionadoras "no serán ejecutivas hasta tanto no haya recaído resolu-

17 La firmeza en la vía administrativa ha sido, además, la regla aplicable bajo la vigencia de la versión anterior de la LTSV, según lo previsto por los arts. 83 y 84, que eran prácticamente iguales a los actuales arts. 88 y 90; sólo que antes el recurso ordinario procedente era el de alzada (antiguo art. 80) y no el de reposición que es el actualmente vigente (art. 82.2 LTSV).

18 El art. 212.3 a) LGT lo ha consagrado expresamente para los recursos y reclamaciones administrativas contra las sanciones tributarias.

19 Vid., sobre los efectos que la falta de resolución expresa del recurso administrativo causa en el plazo de prescripción de la sanción impugnada, Marcos Fernando Pablo, “Un resto prebeccariano en la ordenación de las sanciones administrativas: sobre la prescripción de las infracciones sancionadas y recurridas", REDA, n. ${ }^{\circ} 124,2004$, pp. 570-572. 
ción del recurso ordinario", y así lo han entendido, además, algunos tribunales, aunque otra línea jurisprudencial minoritaria parece haberse pronunciado en sentido contrario ${ }^{20}$.

Por ejemplo, la STSJ de Canarias/Las Palmas, de 10 de septiembre de 1999, Ar. 3300, declara con sumo cuidado:

"la ejecutividad de la sanción no es susceptible de producirse por el mero juego del silencio administrativo, sino que exige la resolución expresa del recurso que, en cada caso, se haya interpuesto contra la resolución (...). Queda excluida en Derecho administrativo sancionador la posibilidad de atribuir a la denegación presunta del recurso (...) capacidad ejecutiva de la sanción (...). En los supuestos en que se haya interpuesto recurso administrativo contra una determinada sanción, dicha firmeza no se produce sino cuando se resuelve tal recurso expresamente".

Así ha terminado por declararlo, también, el TC en su sentencia 243/2006, de 24 de julio. En el supuesto, el recurrente se quejaba de que la Administración había ejecutado la multa sin resolver expresamente el recurso de alzada en su contra sino una vez desestimado por silencio administrativo. La sentencia le da la razón con el argumento de que las previsiones legales vigentes, en especial, el deber que tiene la Administración de resolver expresamente los recursos administrativos aunque sea fuera de plazo y sin vinculación alguna al sentido del silencio,

\begin{abstract}
"excluyen que la resolución objeto de un recurso de alzada pueda alcanzar firmeza hasta que no se desestime éste expresa y totalmente, (...). El deber de la Administración de resolver el recurso (...), resultan incompatibles con la atribución a ésta de la nota de firmeza antes de la resolución expresa de aquél y esa incompatibilidad, que se inicia con la interposición temporánea del recurso, subsiste en tanto no se produzca esa resolución expresa, con independencia de que ello tenga lugar dentro del plazo legal concedido a la Administración o una vez expirado éste. No puede dejar de tenerse en cuenta, (...), el art. 21.2 del Reglamento del procedimiento para el ejercicio de la potestad sancionadora (...).
\end{abstract}

La sentencia, incluso, realiza algunas afirmaciones que no se sabe bien lo que alcanzan a significar:

\begin{abstract}
"tampoco el transcurso del plazo establecido (...) para interponer el recurso contencioso-administrativo contra actos presuntos sin hacer uso del mismo permite lógicamente atribuir firmeza a la resolución administrativa combatida en el recurso de alzada no resuelto (...). La incompatibilidad lógica entre la pendencia en la resolución de la alzada y la firmeza del acto administrativo expreso objeto de la misma subsiste, en consecuencia, (...) al margen de si se ha formulado o no el recurso Contencioso-Administrativo".
\end{abstract}

20 Vid., a este respecto, la STSJ de Andalucía de 5 de marzo de 2007, Ar. 861. También, la STC $91 / 2003$, de 19 de mayo. 
Más recientemente, la STS de 22 de septiembre de 2008, recurso de casación en interés de la Ley n. ${ }^{\circ}$ 69/2005, ha confirmado y completado esa jurisprudencia del TC al corroborar que:

\begin{abstract}
"la resolución sancionadora carece de ejecutividad mientras no se resuelva el recurso administrativo dirigido contra ella (...). La tardanza de la Administración en la resolución del recurso de alzada, aparte de permitir que el interesado formule impugnación en vía jurisdiccional contra la desestimación presunta, (...) en ningún caso (...) determinará la firmeza ni, por tanto, la ejecutividad de la resolución sancionadora".
\end{abstract}

Aunque tanto el TC como el TS se refieran en estas sentencias al recurso administrativo de alzada, su solución también resulta de aplicación, según creo, para el recurso de reposición. Así que hay que entender que tampoco basta con la producción del silencio negativo para que las sanciones de tráfico devengan ejecutables.

En conclusión, para que se pueda pasar a la ejecución forzosa de estas sanciones es necesario que se dicte resolución expresa desestimatoria, aunque sea tardía, del recurso de reposición interpuesto contra ellas.

\title{
VII. LA PRESCRIPCIÓN DE LAS SANCIONES DE TRÁFICO Y LA RESOLUCIÓN EXPLÍCITA DE LA REPOSICIÓN
}

Pero, como decía, la STS de 22 de septiembre de 2008, recurso de casación en interés de la Ley n. ${ }^{\circ}$ 69/2005, completa esa jurisprudencia anterior del TC al añadir que, en tanto no se resuelva el recurso de alzada, "no cabe apreciar la prescripción de la sanción".

A este respecto, hay que referirse primero al art. 92.4 LTSV que regula, con más coherencia que el art. 132.3 LRJPAC, el dies a quo del plazo de prescripción de las sanciones. Así es. Para que la LRJPAC fuese coherente consigo misma (con su art. 138.3) debería decir que la prescripción de la sanción empieza a computarse cuando la resolución ponga fin a la vía administrativa. Pero, en vez de eso, el art. 132.3 dice que "el plazo de prescripción de las sanciones comenzará a contarse desde el día siguiente a aquél en que adquiera firmeza la resolución por la que se impone la sanción". Parece increíble pero el 132.3 exige firmeza, firmeza sin más, no firmeza en vía administrativa, y mucho menos agotamiento de la vía administrativa. Así que ese plazo empieza a correr con carácter general bastante después de que la sanción sea susceptible de ejecución forzosa.

Frente a esa regulación, el art. 92.4 LTSV adelanta el cómputo del plazo de prescripción para las sanciones de tráfico al día de su firmeza en vía administrativa. El 92.4 lo hace bien:

“El plazo de prescripción de las sanciones consistentes en multa pecuniaria será de cuatro años y, el de las demás sanciones, será de un año, computados desde el día siguiente a aquél en que adquiera firmeza en vía administrativa la sanción". 
Por tanto, lo que regula el precepto y lo que argumenta la sentencia parece lógico: la prescripción de la sanción empezará a contar desde que pueda ejecutarse y esto acontece, según el art. 88 y el art. 90 LTSV, desde que alcanza firmeza en vía administrativa. Mientras penda la resolución del recurso administrativo, la sanción no alcanza esa firmeza y, por tanto, su plazo de prescripción no puede echar a correr.

Así que de una resolución sancionadora que esté pendiente de recurso de alzada no puede predicarse la prescripción de la sanción ${ }^{21}$. La misma solución debe aceptarse también para el recurso de reposición contra las multas de tráfico (arts. 88, 90 y 92.4 LTSV). Por tanto, según creo, la prescripción de cuatro años de las multas de tráfico -y la de un año de las sanciones no pecuniarias- sólo computa, caso de interponerse, desde la resolución expresa del recurso de reposición sin que la producción del silencio negativo (art. 82.5 LTSV) pueda determinar el inicio del cómputo.

\section{LOS RESPONSABLES SUBSIDIARIOS DEL PAGO DE LAS MULTAS DE TRÁFICO}

El art. 91.1 LTSV dispone que, por regla general, el propietario del vehículo responderá subsidiariamente en caso de que el conductor sancionado-que es el responsable principal- no pague la multa que le haya sido impuesta (cuando se le declare fallido en los casos de insolvencia) ${ }^{22}$ :

"Los titulares de los vehículos con los que se haya cometido una infracción serán responsables subsidiarios en caso de impago de la multa impuesta al conductor ...”.

\section{Esto con las excepciones previstas en el propio precepto ${ }^{23}$.}

Por su parte, el art. 130.3 LRJPAC acepta y regula con carácter general la responsabilidad solidaria y la subsidiaria en el Derecho Administrativo sancionador. Aunque la jurisprudencia haya declarado que este tipo de responsabilidad no se opone ni al principio de personalidad de la sanción ni, en general, al principio de culpabilidad (STC

21 Esta sentencia guarda una estrecha relación con la anterior del TS de 15 de diciembre de 2004, Ar. 4800 de 2005, que rechazó que pueda computar el plazo de prescripción de la infracción sancionada en vía de recurso administrativo. A esta relación y a las "consecuencias indeseables" que origina para el sancionado -básicamente, "la pervivencia indefinida de una resolución sancionadora que estuviese pendiente de recurso de alzada y de la que no pudiese predicarse la prescripción de la infracción ni de la sanción”- se refiere la propia sentencia de 22 de septiembre de 2008. Por eso mismo, “no (...) descarta (...) que la cuestión abordada en la sentencia de 15 de diciembre de 2004 pueda ser objeto de un nuevo examen cuando haya ocasión para ello".

22 Vid., en este mismo número, Tomás Cano Campos, "La culpabilidad y los sujetos responsables".

23 Estas excepciones son las siguientes: a) Robo, hurto o cualquier otro uso en el que quede acreditado que el vehículo fue utilizado en contra de su voluntad. b) Cuando el titular sea una empresa de alquiler sin conductor. c) Cuando el vehículo tenga designado un arrendatario a largo plazo en el momento de cometerse la infracción. En este caso, la responsabilidad recaerá en éste. d) Cuando el vehículo tenga designado un conductor habitual en el momento de cometerse la infracción. En este caso, la responsabili-

140 dad recaerá en éste 
76/1990, de 26 de abril), lo cierto es que la figura del responsable subsidiario, y no digamos ya del solidario, ha planteado muchos problemas y discusiones en el Derecho Administrativo sancionador ${ }^{24}$.

No obstante, por lo que se refiere a esta regla del art. 91.1 LTSV, a mí me parece bien y considero aceptable que el dueño del vehículo infractor sea el garante y tenga que responder con sus bienes (con el propio vehículo) en caso de que el conductor que sea sancionado no pague la multa. Además, como responsable subsidiario que es, tiene derecho a que luego el sancionado le reembolse todo el dinero que, en concepto de multa, él haya satisfecho previamente. Así lo establece el propio art. 91.3 LTSV.

Sin embargo, parece que esa responsabilidad subsidiaria del dueño del vehículo del art. 91.1 LTSV puede oponerse a la jurisprudencia del TC que ha declarado que a los responsables subsidiarios hay que darles ciertas posibilidades de defenderse (de hecho, la STC 85/2006, de 27 de marzo, parece atribuirles los derechos de defensa propios del responsable directo, lo que, sin duda, constituye un exceso por su parte ${ }^{25}$ ) y que, incluso, ha llegado a considerar que, para responder, tienen que haber participado de algún modo en la comisión culpable de la infracción (STC 76/1990, de 26 de abril; STSJ de la Comunidad Valenciana, de 17 de mayo de 2000, Ar. 1322; y STSJ de Asturias, de 24 de mayo de 2006, Ar. 1429).

Lo que, en todo caso, sí parece desafortunado es que el art. 91.1 c) y d) LTSV haya previsto, también, la responsabilidad subsidiaria del arrendatario a largo plazo o del conductor habitual del vehículo en lugar de la del propietario; y ello porque esto no obedece a la misma finalidad de la previsión anterior; es decir, no parece lógico que se le pueda exigir el pago de la multa a quién no es el dueño del vehículo y, por tanto, no puede responder con él porque, entre otras razones, no se sabrá si será o no titular de algún otro bien con el que afrontar, en su caso, esa responsabilidad.

\section{LA EJECUTIVIDAD DE LAS SANCIONES DE TRÁFICO Y EL DERECHO FUNDAMENTAL A LA TUTELA JUDICIAL CAUTELAR}

\section{Planteamiento}

Como ya se explicó al principio, la opción del legislador sobre la ejecutividad de las sanciones no tiene conexión ni constituye una consecuencia del derecho fundamental a la presunción de inocencia. El art. 88 LTSV -que escojo como regla general-, no así

24 Vid., sobre este tema, Manuel Izquierdo Carrasco, "La culpabilidad y los sujetos responsables", Derecho Administrativo Sancionador, Manuel Rebollo Puig, Manuel Izquierdo Carrasco, Lucía Alarcón Sotomayor y Antonio Bueno Armijo, Lex Nova, 2010, Valladolid, pp. 293-297.

25 Vid. Lucía Alarcón Sotomayor, El procedimiento administrativo sancionador y los derechos fundamentales, op. cit., p. 49. 
las reglas del art. 82 y del art. 81.5 LTSV -que he descartado-, ha optado por exigir que sean firmes en la vía administrativa, con lo que la posibilidad de interponer un recurso administrativo de reposición suspende la eficacia de la sanción impugnada.

A partir de ahí, de la propia normativa de tráfico - del art. 88 LTSV y, también, de las otras reglas- se deduce inequívocamente que la sanción firme en vía administrativa es ejecutiva y que la Administración puede ejecutarla aunque esté impugnada en vía judicial o esté abierto el plazo para hacerlo.

También se infiere de la normativa existente, en el sector del tráfico y con carácter general (arts 88, 89 y 90 LTSV, arts. 111 y 138.3 LRJPAC y art. 135 LJCA), que si se quiere conseguir la suspensión de la sanción hay que solicitarlo en vía contenciosoadministrativa y conseguir una declaración judicial en tal sentido, y que, como mucho, esa suspensión cabrá obtenerla como medida provisionalísima. Mientras tanto, la Administración podrá proceder a la ejecución forzosa de la sanción impuesta.

Conviene completar estas ideas generales con la aclaración de que, para decidir sobre la suspensión de las sanciones recurridas en vía contencioso-administrativa, los criterios que han de barajarse, para otorgarla o denegarla, son los mismos que para cualquier otro acto administrativo (los del art. 111.2 LRJPAC y los del art. 129 y ss. LJCA $)^{26}$. Lo ha declarado, por ejemplo, la STS de 17 de junio de 2008, rec. 1022/2007. No parece, por tanto, que la LJCA haya sentido la necesidad de establecer reglas específicas para facilitar la suspensión judicial de las sanciones ni, en particular, para destacar los efectos de la presunción de inocencia sobre este aspecto. Aquí, por tanto, las sanciones son tratadas como cualquier otro acto administrativo o, si se prefiere, como cualquier otro acto de gravamen. Es decir, por la aplicación de la presunción de inocencia a las sanciones, se podría haber introducido algún matiz -legal o jurisprudencial- más favorable a la suspensión pero, al final, no ha sido asín ${ }^{7}$.

\section{Las matizaciones jurisprudenciales al régimen legal existente en virtud del derecho a la tutela judicial efectiva}

Ahora bien, al margen de todas las previsiones legales vigentes -por lo que ahora interesa, del art. 138.3 LRJPAC y de los arts. 88 y 90 LTSV-, se ha ido desarrollando una jurisprudencia que introduce una corrección en el panorama legislativo descrito. Esa jurisprudencia arranca de la propia STC 66/1984 que, pese a rechazar frontalmente cualquier posible colisión entre la ejecutividad inmediata de las sanciones y la presunción de inocencia, también se la planteó con relación al derecho fundamental a la tutela judicial efectiva y terminó finalmente por declararla.

26 Vid. Manuel Izquierdo Carrasco, “La ejecución de las sanciones”, Derecho Administrativo Sancionador, Manuel Rebollo Puig, Manuel Izquierdo Carrasco, Lucía Alarcón Sotomayor y Antonio Bueno Armijo, Lex Nova, 2010, Valladolid, pp. 901-902.

27 Vid. Lucía Alarcón Sotomayor, El procedimiento administrativo sancionador y los derechos fundamentales, op. cit., pp. 481-482. 
Hay que señalar, no obstante, que esa jurisprudencia del TC ha consagrado una solución más moderada que una línea jurisprudencial anterior del TS, mucho más radical, que defendió la ejecutividad de las sanciones únicamente desde que fuesen firmes, pero firmes a secas, esto es, en las vías administrativa y judicial. Muestra de esa jurisprudencia fueron las SSTS de 17 y 21 de julio de 1982, Ars. 4428 y $4442^{28}$. La primera, por ejemplo, declaró que el cumplimiento inmediato de una sanción de suspensión de funciones de un año impuesta a un funcionario sin esperar a su firmeza lesiona el derecho a la tutela judicial efectiva, pues la imposibilidad de deshacer los efectos de su cumplimiento, en caso de anularse posteriormente en vía judicial, provoca una situación de indefensión:

“La cuestión (...) es (...) si, (...), pueden llevarse a efecto con carácter inmediato (...) en virtud del privilegio de ejecutividad de los actos administrativos, o bien si (...) tal efectividad sólo podrá válidamente imponerse cuando los actos sancionadores hayan ganado firmeza, de tal manera que la interposición del previo recurso administrativo, en este caso de reposición, y el ulterior jurisdiccional o contenciosoadministrativo, producen efectos suspensivos respecto del mencionado cumplimiento (...). Parece evidente que la imposición del cumplimiento inmediato de la sanción, sin esperar a su firmeza, al funcionario recurrente vulnera el art. 24.1 de la Constitución".

Pero esa jurisprudencia extrema que postuló la firmeza de las sanciones para que la Administración pudiese ejecutarlas no llegó a consolidarse en los años siguientes sino que fue atemperada o amortiguada, como digo, por la STC 66/1984 que adelanta e introduce la doctrina del TC que sigue siendo aplicable en la materia.

La sentencia 66/1984 también se enfrenta con la posible incompatibilidad existente entre la ejecutividad inmediata de las sanciones y el derecho a la tutela judicial efectiva y resuelve el problema de una más forma ambigua, pero que resulta aceptable. Y, así, esta sentencia, y todas las que han continuado y completado su doctrina, llegan a la conclusión de que, aunque el derecho a la tutela judicial efectiva no se opone totalmente a la ejecutividad de las sanciones, sí la retrasa hasta que el juez haya podido pronunciarse sobre las medidas cautelares solicitadas en el recurso contra ella. Es decir, que la posibilidad de ejecutar forzosamente la sanción queda a la espera de que se resuelva judicialmente sobre su suspensión cautelar; no a la espera de que se resuelva por sentencia el recurso contencioso-administrativo, como se deducía de la jurisprudencia anterior más radical. Dicen, por ejemplo, las SSTC 66/1984,

28 Vid., sobre estas sentencias, Juan Alfonso Santamaría Pastor, “Tutela judicial efectiva y no suspensión en vía de recurso", RAP, n. ${ }^{\circ}$ 100-102, vol. II, 1983, pp. 1609-1627; Javier Barcelona Llop, Ejecutividad, ejecutoriedad ..., op. cit., pp. 412-416; José María Fernández Pastrana, “La influencia de la Constitución en la jurisprudencia sobre suspensión de los actos administrativos”, RAP, n. ${ }^{\circ} 120,1989$, pp. 284-287; Miguel Sánchez Morón, "El derecho a la tutela judicial efectiva como límite a la ejecutividad de los actos administrativos”, REDA, n. ${ }^{\circ}$ 35, 1982, pp. 669-674; Joan Manuel Trayter Jiménez, Manual de Derecho disciplinario de los funcionarios públicos, op. cit., pp. 365-371; y Fernando López Ramón, “Límites constitucionales de la autotutela administrativa", $R A P$, n. ${ }^{\circ} 115,1988$, pp. 57-97. 
de 6 de junio (sobre multas en materia de viviendas de protección oficial); 78/1996, de 20 de mayo (sobre sanción disciplinaria a funcionario); y 243/2006, de 24 de julio (sobre multa por riesgos laborales), que:

"la ejecutividad de los actos sancionadores ... no es algo indefectiblemente contrario al derecho a la tutela judicial efectiva (...). El derecho a la tutela se satisface facilitando que la ejecutividad pueda ser sometida a la decisión de un Tribunal y que éste, con la información y contradicción que resulte menester, resuelva sobre la suspensión".

El TS también ha terminado por pronunciarse en este sentido. Muestra de ello son las SSTS de 4 de diciembre de 1999, Ar. 9763 (sobre una sanción de cancelación de la inscripción en el Registro especial de empresas de seguridad privada); y de 18 de septiembre de 2001, Ar. 430 de 2002; de 19 de diciembre de 2001, Ar. 10119; de 4 de febrero de 2002, Ar. 1084; de 3 de diciembre de 2002, Ar. 866 de 2003; y de 5 de febrero de 2004, Ar. 925 (todas sobre sanciones tributarias).

Especialmente ilustrativa, a este respecto, es la STC 341/1993, de 18 de noviembre, que, entre otras cosas, se pronuncia sobre la constitucionalidad del art. 38.1 LPSC que consagra la ejecutividad de las sanciones en este sector "desde que la resolución adquiera firmeza en vía administrativa”, como hace también el actual art. 88 LTSV. A la alegación de que lesiona el derecho a la tutela judicial efectiva, se opone la sentencia diciendo que el art. 38.1 LPSC:

\begin{abstract}
"se limita a afirmar la ejecutividad de las sanciones impuestas en aplicación de la propia Ley, una vez sean firmes en vía administrativa, y es del todo claro que esta previsión legal en nada impide, dificulta o condiciona el posible recurso jurisdiccional contra el acto de sanción ni en nada menoscaba tampoco, la posibilidad de solicitar y de obtener de los Tribunales la suspensión cautelar del acto impugnado".
\end{abstract}

En el mismo sentido, se ha pronunciado, también, la STC 259/2007, de 19 de diciembre, con relación al art. 63.4 de la Ley de Derechos y Libertades de los Extranjeros en España, tras su reforma por Ley 8/2000, según el cual “la ejecución de la orden de expulsión en estos supuestos se efectuará de forma inmediata”.

\title{
3. Según la jurisprudencia, las sanciones no pueden ejecutarse mientras que el juez no haya podido decidir sobre su suspensión cautelar
}

En definitiva, las sanciones no pueden ejecutarse mientras que el juez no haya podido pronunciarse sobre su suspensión: aunque se hayan notificado correctamente o pongan fin o sean firmes en vía administrativa. Esto también vale para las multas de tráfico, aunque el TC no lo haya proclamado expresamente para ellas y con independencia de la regla de la LTSV que se entienda aplicable para hacerlas 144 81.5 LTSV. 
En esto consiste la matización jurisprudencial al régimen legal antes expuesto. No es poco, pero no supone que la mera interposición del recurso contencioso-administrativo paralice la ejecutividad o que haya que esperar a la sentencia o que haga falta que sea firme. Tampoco significa que el juez, para decidir sobre la suspensión de las sanciones, tenga que utilizar criterios más favorables que los generales y, menos todavía, que esté constreñido a otorgarla siempre ${ }^{29}$.

Aun así, la matización conlleva efectos trascendentales. Los siguientes:

La primera consecuencia es que la sanción no puede ejecutarse ni antes ni durante el plazo de interposición del recurso contencioso-administrativo. Así que, a pesar de lo dispuesto en la LTSV, las sanciones no son ejecutivas desde que alcanzan firmeza en vía administrativa -art. 88 LTSV- o desde que se notifican expresamente -art. 82.1 LTSV- o a los treinta días naturales de la notificación de la denuncia -art. 81.5 LTSV-, sino, como muy pronto, cuando finalice el plazo de formulación del recurso contencioso si es que el sancionado no lo interpone.

En segundo lugar, si se interpone el recurso contencioso, caben dos posibilidades. Por un lado, puede que el recurrente haya pedido la suspensión cautelar de la sanción impugnada, en cuyo caso, la Administración sólo podrá ejecutarla cuando el juez dicte auto denegando esa petición, de modo que la ejecutividad de las sanciones sufre un nuevo retraso respecto de lo previsto en el art. 88 LTSV.

Por otra parte, puede que el recurrente no solicite la suspensión. Si así fuera, la impugnación judicial de la sanción sin petición expresa de suspensión la convierte en ejecutiva y, por tanto, ya puede ser ejecutada forzosamente por la Administración ${ }^{30}$.

Cabría, incluso, una tercera posibilidad que complicaría más las cosas porque la suspensión de la sanción podría pedirla el sancionado en un momento posterior a la interposición del recurso judicial de forma que, cuando lo hiciera, volvería a producirse un nuevo impedimento para poder ejecutarla.

El resultado de esta jurisprudencia es que el derecho fundamental a la tutela judicial efectiva o, más bien, el que se extiende a la tutela judicial cautelar paraliza la eficacia de las sanciones y la supedita al cumplimiento de uno de estos tres requisitos: el agotamiento del plazo establecido sin impugnación judicial de la sanción; o la impugnación judicial sin petición expresa de suspensión; o la denegación explícita de la suspensión cautelar solicitada en vía judicial. Si no se cumple alguno de ellos, la Administración no podrá ejecutar la sanción, a pesar de lo dispuesto en los arts. 88, 89 y 90

29 Vid. Javier Barcelona Llop, Ejecutividad, ejecutoriedad..., op. cit., p. 411; y Joan Manuel Trayter Jiménez y Vicenç Aguado i Cudolà, Derecho Administrativo Sancionador: Materiales, op. cit., pp. 200-202.

30 Vid. Tomás Cano Campos, “Artículo 51”, Comentarios a la Ley Reguladora de las Bases del Régimen Local, dirigidos por Manuel Rebollo Puig, vol. II, Tirant lo Blanch, 2007, Valencia, pp. 1282-1283. 
LTSV$^{31}$. Así lo explica y lo reconoce también la doctrina para las sanciones administrativas con carácter general ${ }^{32}$.

\section{La llamativa indiferencia del legislador hacia esa jurisprudencia y los problemas que ello genera}

Hay que tener en cuenta que todo esto ha sido consagrado por vía jurisprudencial y que, frente a ella, el legislador ha establecido un régimen distinto que, aunque no se opone radicalmente a esa jurisprudencia sí la ignora por completo. Es decir, es asombroso que esa jurisprudencia no haya desembocado en la declaración de inconstitucionalidad de alguno de los preceptos legales que anticipan la ejecutividad de las sanciones, sobre todo, de los que la consagran con carácter inmediato; y, más aun, lo es que el legislador no haya hecho ninguna reforma para incorporarla en sus Leyes. Sobre esto, quiero hacer especial hincapié en que me resulta muy llamativo que ni la Ley 18/2009 ni la LRJPAC -ni muchas otras- hayan reflejado nada de esa jurisprudencia del TC y que, por el contrario, en concreto, me refiero ahora al art. 82.1 LTSV, se consagre la ejecutividad de las sanciones desde su notificación al interesado.

Esa indiferencia de las Leyes vigentes hacia la jurisprudencia existente llama mucho la atención. La razón, creo yo, por lo que se refiere a la Ley 18/2009, es que el legislador no la ha considerado relevante o efectiva en el sector del tráfico. Sobre esto volveré después.

El caso es que esa falta de previsión legal ha generado inseguridad y problemas prácticos de todo tipo que también se han planteado en las sanciones de tráfico. Uno de ellos es que la Administración no tiene cómo enterarse de si se ha planteado o no el recurso contencioso-administrativo ni de si se ha pedido o no la suspensión cautelar. Esto sólo lo conocerá bastante tiempo después y, sin embargo, esa información resulta esencial para que pueda proceder a la ejecución de las multas impugnadas.

31 Estas reglas pueden completarse con la aclaración de que todo esto es sin perjuicio de las medidas provisionales que la Administración pueda adoptar, en su caso, para asegurar la eficacia de la resolución sancionadora en tanto no pueda ejecutarse y hasta que el juez decida sobre las medidas cautelares solicitadas. Es decir, en defecto de previsión específica en la nueva LTSV, hay que entender aplicable el régimen general del art. 138.3, párrafo segundo, LRJPAC que establece que "en la resolución se adoptarán, en su caso, las disposiciones cautelares precisas para garantizar su eficacia en tanto no sea ejecutiva".

32 Vid. Juan Alfonso Santamaría Pastor, Principios de Derecho Administrativo General, vol. II, $2^{\mathrm{a}}$ edic., lustel, 2009, Madrid, pp. 428-430; Blanca Lozano Cutanda, La extinción de las sanciones administrativas y tributarias, Marcial Pons, 1990, Madrid, p. 70; Fernando López Ramón, “Límites constitucionales de la autotutela administrativa”, $R A P$, n. ${ }^{\circ} 115,1988$, p. 79; Joan Manuel Trayter Jiménez, "El procedimiento administrativo sancionador", Justicia Administrativa. Revista de Derecho Administrativo, n. ${ }^{\circ}$ extraordinario de 2001, Lex Nova, 2001, Valladolid; p. 82; y Javier Barcelona Llop, "De la ejecución forzosa de los actos administrativos a la ejecución forzosa de las sentencias contencioso-administrativas”, $R A P$, n. ${ }^{\circ} 127,1992, \mathrm{pp}$. 171-210; y Ejecutividad, ejecutoriedad ..., op. cit., pp. 440-443.

En contra, vid. Eduardo García de Enterría y Tomás-Ramón Fernández Rodríguez, Curso de Derecho 146 Administrativo, vol. II, , op. cit., p. 203; María Rubio de Casas, “De nuevo sobre la potestac..., op. cit., p. 482; y Ramón Parada Vázquez, Derecho Administrativo /..., op. cit. p. 532. 
Sería conveniente, por tanto, que se articularan mecanismos legales para que la Administración tuviera esa información lo antes posible.

Frente a un vacío legal generalizado, la única norma que, salvo error u omisión, se ha adecuado a esa jurisprudencia constitucional y ha afrontado, además, el problema apuntado es el Real Decreto 2063/2004, de 15 de octubre, que aprueba el Reglamento General del Régimen Sancionador Tributario.

Artículo 29. Suspensión de la ejecución de las sanciones.

1. "La suspensión de la ejecución de las sanciones, pecuniarias y no pecuniarias, como consecuencia de la interposición en tiempo y forma de un recurso o reclamación en vía administrativa se aplicará automáticamente por los órganos competentes, sin necesidad de que el interesado lo solicite.

2. Una vez la sanción sea firme en vía administrativa, los órganos de recaudación no iniciarán las actuaciones del procedimiento de apremio mientras no concluya el plazo para interponer el recurso contencioso-administrativo. Si durante ese plazo el interesado comunica a dichos órganos la interposición del recurso con petición de suspensión, ésta se mantendrá hasta que el órgano judicial adopte la decisión que corresponda en relación con la suspensión solicitada".

Este precepto, aunque sólo sea aplicable para las sanciones tributarias, sirve para orientar sobre la situación y la forma de proceder de la Administración y del sancionado más allá de este ámbito. De hecho, alguna sentencia del TS parece haber previsto su misma solución -en concreto, la carga del sancionado de informar a la Administración sobre la impugnación judicial y la solicitud de suspensión cautelar si quiere que esa suspensión se mantenga- en otros sectores distintos del tributario ${ }^{33}$.

\section{La regla de la jurisprudencia es una solución intermedia entre sólo exigir para la ejecutividad la firmeza administrativa o la firmeza total}

Como se comprenderá, todo esto no equivale a decir que las sanciones no son ejecutivas hasta que sean completa y definitivamente firmes, pues pueden ser eficaces y se pueden ejecutar sanciones que todavía penden de una sentencia contencioso-administrativa y que, por tanto, no han alcanzado esa firmeza. Pero tampoco se trata de exigir para su ejecutividad sólo su firmeza en vía administrativa: ya lo es, en el tráfico, la confirmada en reposición (art. 88 LTSV) y, sin embargo, no será ejecuti-

33 La STS de 15 de abril de 2003, Ar. 4183, sobre sanciones disciplinarias que impedían que varios candidatos se presentasen a una elección de la junta de gobierno del colegio profesional de enfermeros, ve bien que las sanciones fueran ejecutadas desde su firmeza en vía administrativa, aunque se hubiera interpuesto contra ellas tres días antes de la elección recurso contencioso-administrativo con petición de suspensión, pues la Administración no tuvo "en tiempo hábil conocimiento de cualquier resolución judicial que afectara a la ejecutividad de los actos administrativos que estaba aplicando". 
va hasta que pase el plazo del recurso contencioso-administrativo o ni siquiera ello si se formula y se insta la suspensión. Es decir, la de la jurisprudencia es una solución intermedia entre sólo exigir para la ejecutividad la firmeza administrativa o la firmeza total ${ }^{34}$.

\section{La posible extensión de esa jurisprudencia a todos los actos administrativos de gravamen y no sólo a los sancionadores}

Además, y esto es muy importante, hay que tener en cuenta que en esta jurisprudencia no está presente la presunción de inocencia, que es una garantía exclusiva en la imposición de las sanciones, sino que el TC la ha elaborado a partir del derecho a la tutela judicial efectiva, que se tiene para impugnar por ilegal cualquier decisión de la Administración y no sólo las de carácter sancionador, por lo que este derecho podría llevar a extender esa tendencia de retrasar la ejecutividad de las sanciones a otros actos administrativos de gravamen no sancionadores. Es decir, si la demora que se ha impuesto para poder ejecutar la sanción obedeciera a las exigencias de la presunción de inocencia, sería comprensible y estaría plenamente justificada la distinción, puesto que este derecho fundamental sólo rige para lo punitivo. Pero, estando el fundamento en la tutela judicial efectiva, parece que igual conclusión habría de alcanzarse para todos los actos administrativos de gravamen. Hay autores que ya lo han advertido y también se han pronunciado en este sentido35. Sin embargo, nuestros tribunales sólo

34 A este respecto, importa destacar aquí que para la pérdida parcial de puntos del carné de conducir, parece que la LTSV (art. 67.3, disposición adicional primera y anexo II) prevé que se imponga en la misma resolución de la multa. Por lo que respecta a su ejecución, la disposición adicional primera LTSV dice que procede “cuando (el) (...) conductor sea sancionado en firme en vía administrativa”. A partir de ahí, continúa el precepto, “los puntos (...) quedarán descontados de forma automática y simultánea en el momento en que se proceda a la anotación de la citada sanción en el Registro de conductores e infractores”. El art. 67.3 LTSV, sin embargo, habla de firmeza a secas y no de firmeza en vía administrativa, aunque ello obedezca, lo más seguro, a un nuevo desliz del legislador. Lo confirma el Anexo II que insiste en la firmeza en vía administrativa de la sanción para que se produzca esa detracción de puntos.

Por lo que respecta a la pérdida total de todos los puntos que se tuviesen asignados, el art. 63.6 LTSV dice que, "una vez constatada" esta circunstancia, la Administración dictará un "acuerdo por el que se declara la pérdida de vigencia de su permiso o licencia de conducción". Este acuerdo ha de notificarse al interesado, según el propio 63.6 LTSV, en el plazo de quince días. Pero esto plantea muchos problemas. Por ejemplo, si hay que seguir un nuevo procedimiento administrativo para poder dictar ese acuerdo, o si en su caso ese acuerdo es recurrible, o cuál es el recurso que procede interponer o si ese recurso suspende o no su eficacia. Las posibles respuestas se encuentran o se deducen del Reglamento General de Conductores, aprobado por Real Decreto 818/2009, de 8 de mayo. En concreto, de su art. 37 y, en menor medida e indirectamente, de su art. 39. En primer lugar, cabe afirmar que sí hay que seguir un nuevo procedimiento con un acto formal de iniciación, audiencia al interesado, resolución y notificación. En segundo término, la competencia para ello corresponde al jefe provincial de tráfico. Por último, y como nada se prevé expresamente, parece que hay que declarar que la resolución no agota la vía administrativa y que, por tanto, es recurrible mediante el recurso de alzada.

35 Javier Barcelona Llop, Ejecutividad, ejecutoriedad ..., op. cit., pp. 466 y 473; Mercedes Lafuente Benaches, El régimen disciplinario de los funcionarios públicos de la Administración del Estado, Tirant lo blanch, 1996, Valencia, pp. 136-137; y Joaquín Eugenio ARRIBAS LÓPEZ, "Notas sobre la ejecutividad de las 148 tualidad Aranzadi, año XVI, n. ${ }^{\circ} 702,6$ de abril de 2006, pp. 1-5. 
han acogido por ahora estas matizaciones a la ejecutividad para las sanciones propiamente dichas y no para otros actos administrativos que sean desfavorables al interesado. Aunque nada impide, como digo, que en el futuro pueda optarse por esta otra solución.

\section{La escasa efectividad de esa jurisprudencia en las sanciones de tráfico}

Con todo, y como adelanté, esa jurisprudencia del TC y, luego también, del TS ha sido curiosamente ignorada por el legislador, que no la ha previsto ni en las nuevas Leyes sancionadoras sectoriales que ha ido aprobando ni en las reformas operadas en las Leyes anteriores, con la excepción ya mencionada del ámbito tributario.

Esto es lo que ha ocurrido, precisamente, en la Ley 18/2009 de reforma de la LTSV: ni en ella ni en las anteriores reformas ni en el texto original de 1990 hay atisbo alguno de esa doctrina constitucional.

Pues bien, para el tráfico, quizá, la causa pueda estar en la escasa relevancia que parece tener esa jurisprudencia en este sector. Es decir, el legislador sabe que la regla general de la jurisprudencia es la no suspensión de las sanciones pecuniarias impugnadas en vía contencioso-administrativa (STS de 18 de marzo de 2000, Ar. 3073; ATS de 19 de septiembre de 2000, Ar. 7655; y STS de 17 de junio de 2008, rec. 1022/2007), o bien porque no se acrediten los daños que producirá la inmediata ejecución o bien porque ésta se considere una exigencia del interés público por razones o de ejemplaridad o de rápida obtención de fondos por parte de la Administración ${ }^{36}$.

A este respecto, hay que tener en cuenta que las sanciones de tráfico por antonomasia, ahora más que nunca, son las multas y que éstas tienen una cuantía escasa (art. 67 y art. 68 LTSV) si se las compara con las que pueden imponerse en otros sectores del ordenamiento (defensa de la competencia, protección de datos, banca, mercado de valores). Así que lo habitual, conforme a los criterios generales de los arts. 129 y 130 LJCA -que prevén la medida cautelar sólo para el caso de que su denegación pueda hacer perder la finalidad legítima al recurso-, es que los tribunales denieguen las peticiones de suspensión cautelar de las multas de tráfico que tengan que enjuiciar.

A esta situación tan poco proclive al otorgamiento de la suspensión contribuye el hecho de que las multas son sanciones de efectos fácilmente reversibles y, más aun, si son poco elevadas. Es decir, como dice la STS de 18 de junio de 2008, rec. 1022/2007:

36 Vid. Manuel Izquierdo Carrasco, “La ejecución de las sanciones”, op. cit., pp. 902-904. Tampoco suele paralizar la eficacia de las restantes sanciones. Vid. los argumentos de los AATS de 6 y 22 de marzo de 2000, Ars. 2898 y 3218, que, aunque se refieren a sanciones disciplinarias impuestas a jueces, son susceptibles de aplicación general. 
"tratándose de desembolsos, son susceptibles de devolución en caso de sentencia estimatoria del recurso, por lo que desaparece una posible inefectividad de esa sentencia en el futuro dada la solvencia que hay que presumir de la Administración".

Por tanto, es muy fácil deshacer los efectos de las multas que ya hayan sido satisfechas en el caso de que se dicten sentencias estimatorias que las anulen. Esto, por contra, no pasa con otras sanciones, por ejemplo, con la suspensión de empleo, con la prohibición del ejercicio de una profesión o con la privación de ciertas licencias ${ }^{37}$. En estos casos, puede que sea imposible materialmente la total reposición o reintegración a la situación jurídica anterior al cumplimiento de la sanción, en el supuesto de que una sentencia la anule y ya se haya ejecutado. Y esta imposibilidad puede causarle al recurrente una situación de indefensión material que lesione su derecho a la tutela judicial efectiva.

Pues bien, a mi modo de ver, la jurisprudencia que retrasa la ejecutividad de las sanciones hasta el momento en que el juez contencioso-administrativo pueda pronunciarse sobre su suspensión cautelar puede considerarse correcta para las sanciones de efectos irreversibles, sobre todo, para las especialmente gravosas que no admitan una verdadera y real reparación o compensación ulterior en el caso de que un juez decida anularlas. Para ellas, creo que sí es posible -posible pero no obligado- argumentar que un adelanto en la ejecutividad podría lesionar el derecho a la tutela judicial eficaz. Pero, para otras sanciones y, en especial, para las multas de tráfico esa jurisprudencia no está bien pensada y no tiene sentido aplicarla. Por eso, la Ley 18/2009 de reforma de la LTSV ha hecho bien en ignorarla y no incluirla en su articulado. Soy consciente de que esa jurisprudencia se fraguó, principalmente, pensando en las multas tributarias pero ni siquiera eso me hace encontrarle una explicación satisfactoria. Y, con todo, se trata de una solución a medias porque la LTSV también prevé, además de las multas, la suspensión de autorizaciones a autoescuelas y similares y esta explicación no sirve para esa clase de sanciones.

Creo, en definitiva, que es conforme con la CE -y con la potestad sancionadora de la Administración que la CE consagra en el art. 25.1- que las multas de tráfico

37 Así, la reciente STS de 6 de mayo de 2009, recurso de casación 1388/2008, confirma la suspensión cautelar de una sanción de efectos 'irreversibles' por dopaje en el deporte, debido a la existencia de periculum in mora y a que el interés público no precisa de su ejecutividad inmediata. En el caso enjuiciado, tras la impugnación judicial de una sanción de suspensión de licencia federativa por un periodo de dos años, la sentencia de instancia otorga la suspensión cautelar de la sanción solicitada por el recurrente. La Administración sancionadora impugna esta medida cautelar, al considerar que la sentencia de instancia ha interpretado de modo incorrecto el concepto jurídico indeterminado de "pérdida de la finalidad legítima del recurso", recogido en el art. 130.1 LCA. Sin embargo, la Sala confirma la adopción de la suspensión, razonando que "su ejecución daría lugar a una situación irreversible, solo reparable (...) mediante la correspondiente indemnización económica. Pero la obtención de esta no es lo que persigue prioritariamente el recurso interpuesto, pues su finalidad legítima es, antes o más bien, no soportar o sufrir de modo irreversible una sanción que la parte reputa injusta". A ello se sumaría que, si bien "el interés público exige que la sanción sea ejecutada, lo es también que en el concreto caso de autos no llega a percibirse que tal interés exija que lo sea ya, urgentemente, sin esperar el tiempo preciso para que el órgano judicial pueda pronunciarse sobre la acomodación a Derecho de la sanción impuesta". 
puedan ejecutarse desde que sean o puedan ser confirmadas por la propia Administración -cuando no quepa contra ellas ningún recurso administrativo ordinario-, que es la solución equivalente a la prevista para las sentencias penales, que son susceptibles de ejecución desde que sean o puedan ser confirmadas por un tribunal -cuando no sea posible impugnarlas a través de un recuso judicial ordinario (art. 141 LECrim)-.

Por tanto, la opción de los arts. 88 y 90 LTSV de que sean ejecutivas cuando alcancen firmeza en vía administrativa me parece una solución coherente y dudo mucho que el TC la declarara inconstitucional si el problema llegara a planteársele en este ámbito ${ }^{38}$.

\section{REFERENCIA A LOS MEDIOS DE EJECUCIÓN FORZOSA DE LAS SANCIONES DE TRÁFICO}

Para las sanciones de tráfico, resultan aplicables las reglas generales sobre medios de ejecución forzosa de los actos administrativos. Así, si se trata de sanciones de multa, lo que procede es el apremio sobre el patrimonio, de modo que se aplica el RGR igual que si se tratase de ejecutar cualquier acto administrativo que imponga el deber de pagar una cantidad de dinero. Si acaso, la legislación sectorial puede prever para cualquier acto administrativo -incluidos los sancionadores- alguna singularidad con repercusión directa en el procedimiento de ejecución, por ejemplo, ciertas garantías legales o, por lo que aquí interesa, la existencia de responsables subsidiarios o solidarios. De hecho, esto es lo que sucede, como se analizó antes, en materia de tráfico.

Y, si se trata de una sanción que impone un hacer o un no hacer, procederá la ejecución subsidiaria o la multa coercitiva o la compulsión sobre las personas, según el contenido del deber y lo previsto en la correspondiente Ley sectorial, porque el art. 99.1 y el art. art. 100.1 LRJPAC exigen para la utilización de la multa y de la compulsión una previsión legal específica. A este respecto, conviene aclarar que la Ley de reforma ha suprimido del texto de la LTSV la sanción de suspensión temporal del permiso de conducción y del de circulación.

En cuanto a la ejecución de la sanción de suspensión y retirada de autorizaciones impuesta a centros de enseñanza y formación y a centros de reconocimiento de conductores en los supuestos del art. 65.6 e) LTSV, hay que estar a lo dispuesto en el art. 67.2, in fine, LTSV que prevé una nueva sanción por incumplimiento de sanción que recuerda a las penas judiciales impuestas por quebrantamiento de condena: "la realización de actividades durante el tiempo de suspensión de la autorización llevará apa-

38 A lo sumo, podría dictar una sentencia interpretativa que impusiese una interpretación de esos preceptos conforme a esa jurisprudencia suya anterior, a cambio de no anularlos ni declararlos inconstitucionales. 
rejada una nueva suspensión por un tiempo de seis meses al cometerse el primer quebrantamiento, y de un año si se produjese un segundo o sucesivos quebrantamientos".

Por su parte, el art. 37 Real Decreto 818/2009, de 8 de mayo, que aprueba el Reglamento General de Conductores (en adelante, RGC) se ocupa del procedimiento para la declaración de pérdida de vigencia del permiso de conducción por la pérdida de todos los puntos asignados -art. 63.6 LTS-; aunque hay que tener presente que la LTSV no le ha atribuido carácter sancionador a esta medida: ni antes ni después de la última reforma. En cambio, la jurisprudencia sí lo ha hecho, como antes se indicó. Precisamente, para la ejecución forzosa de la pérdida del permiso de conducir por pérdida de todos los puntos, el art. 37.2, párrafo segundo, RGC establece una curiosa forma de compulsión sobre las personas que no procedería conforme a las reglas generales -conforme al art. 100.2 LRJPAC- por tratarse de una resolución que impone una obligación personalísima de hacer. El precepto dice así: “declarada la pérdida de vigencia, el interesado deberá entregar el permiso o licencia de conducción en la Jefatura Provincial de Tráfico la cual, de no hacerlo, ordenará su retirada por los Agentes de la autoridad".

Recibido: 7 de julio de 2010

Aceptado: 26 de julio de 2010 